Valóságos könyvtár - könyvtári valóság. Könyvtár- és információtudományi tanulmányok 2016. Szerk. Kiszl Péter, Boda Gáborné Köntös Nelli.

Budapest, ELTE BTK Könyvtár- és Információtudományi Intézet. 2017. 147-152.

\title{
VIRTUALIZÁLÓDÓ ÖRÖKSÉGÜNK VALÓSÁGOS IGÉNYEK TÜKRÉBEN
}

\author{
FODOR JÁNOS \\ ELTE BTK KITI, egyetemi adjunktus
}

\begin{abstract}
ABSZTRAKT
Az előadás gondolatmenete arra hívja fel a figyelmet, hogy a könyvtárak közösségi médiajelenlétének hiányosságai és torzulásai mögött részben a gyűjteményi digitalizálás eredményessége állhat. A nagy, digitalizált dokumentumgyújtemények korában meglazul a kapcsolat a könyvtáros és a feldolgozott digitális tartalom között. A személyes kapcsolat, útmutatás igényét a könyvtárosok a közösségi médiában pótolják, mert a könyvtári honlapok látogatottsága csökken a digitalizált gyüjtemények, repozitóriumok szerepének növekedésével. Fontos megőrizni a könyvtároskép kreatív, tájékozódásban, kutatásban, megosztásban is példát mutató vonásait, ki kell alakítani a könyvtári webjelenlét új formáit, melyek az általános közösségi felületeknél alkalmasabbak a könyvtár igényeihez, s biztosítják a könyvtáros szakemberek kreatívabb tájékoztatási munkáját. Az alkotó könyvtáros képének rehabilitálása nem csak a szakmát teheti vonzóbbá, de egybevág a jövő könyvtáráról, mint nyitott múhelyről és közösségi térről alkotott elméletekkel. A gondolatmenet alátámasztására történeti és kortárs példát egyaránt hozhatunk. A legendásan polihisztor könyvtárvezető, Lipták Pál bibliofil könyvsorozata jó példa az olvasók, könyvtárosok és alkotók szoros kapcsolódására, s máig érvényes modellt valósított meg a rétegigényeket kiszolgáló print-on-demand korában. A Poesis Hungarica könyvsorozat emlékhonlapját Intézetünk készítette el nemrég. Tartalomszolgáltatást kutató múhelyünk számos projektje, gyakorlata és együttmúködése szolgálja azt a célt, hogy segítse, bátorítsa a jövő könyvtárosait tehetségüket kibontakoztatni és érdeklődésükkel a hálózati tájékoztatást szolgáló projekteket, gyújtéseket, alkotásokat kezdeményezni.
\end{abstract}

A hazai gyűjteményi digitalizálás a kezdetektől fogva fontos eredményeket ért el, s napjainkra a virtuálisan lapozható könyvek, sajtótermékek, képek és fotográfiák olyan mennyiségét sikerült közzétenni, amely a múzeumi és egyéni memóriaintézményekhez köthető digitális tudáskinccsel együtt bátran nevezhető kritikus tömegnek, az átlag webfelhasználó figyelmét is megragadó tudásbázisnak.

A konferencia digitalizálási szekciójában a gyújteményi digitalizálás hazai szakemberei és irányítói mutatták be munkájukat és legújabb fejlesztéseiket az elmélyült kutatásra épülő, aprólékos kézirat-digitalizálástól és filológiai igényű szövegkiadástól az intézményikönyvtári digitalizálási stratégiákon és tömeges hozzáférhetővé tételt célzó projekteken át a virtuális gyűjtemény-reprezentációs fejlesztésekig, interaktív felülettervezési megoldásokig. A könyvtárak és a digitalizálással foglalkozók közös és érthető vágya, hogy a digitalizált értékek szolgáltatása jól szervezett, korszerű rendszerekben, adatbázisokba szervezve, hozzáértő szakemberek felügyelete alatt váljon elérhetővé és maradjon hozzáférhető lehetőleg a digitális idők végezetéig. 


\section{FODOR JÁNOS}

Miközben lelkesedéssel és őszinte örömmel üdvözöljük az ezért dolgozó szakembereket, programozókat és fejlesztőket a mindennapok szakmai híreiben csakúgy, mint a konferencián, talán nem ünneprontás, sőt, a Magyar Tudomány Ünnepén éppen a tudományos józansághoz illő, ha elgondolkozunk a digitalizálódási folyamat esetleges mellékhatásain, a jelenlegi trendekkel együtt járó problémákat keresve.

A digitális állományokat szolgáltató gyűjteményekben, adatbázisokban a könyvtári állomány virtuális otthonra lel, de el is szakad a könyvtárosok zömétól. A létrejött keretszolgáltatásoktól nem várhatunk el többet annál, hogy felhasználóbarátok és könyvtártudományi szempontból szofisztikáltak, jól kereshetőek legyenek, tételeik megosztása, netán címkézése és kommentálása lehetséges legyen. Intézeti kutatásaink során ${ }^{1}$ egyre több olyan adatbázist találunk, amely részben vagy teljesen teljesíti e feltételeket. A virtuális gyüjtemények korszerūen tartása, gyarapítása és folyamatos fejlesztése mellett lesz-e ugyanakkor - s elvárható-e egyáltalán - olyan könyvtáros munkatársi közeg a pályázati pénzekkel vagy reprezentatív céllal létrejött weboldalak mögött, amely magáénak érezve a közzétett állományt, napról-napra elősegíti annak megismerését, olvasók figyelmébe ajánlását?

Korábbi kutatásaink ${ }^{2}$ megmutatták, hogy továbbra is hiszünk a saját felügyeletủ weboldalainkban, illetve abban, hogy online identitásunk alapjaként hosszú távon is népszerû marad honlapunk, ahogy abban is, hogy tőlünk függetlenül megjegyzik és használni kezdik majd a létrejött adatbázisok, digitális szövegtárak, repozitóriumok weboldalait is. Napjainkban, amikor olvasóink többsége szabadidejében a közösségi médiára fordítja figyelme és online töltött ideje nagy részét, egyre nyilvánvalóbb, hogy ezt az időt jórészt a böngészésen, „szörfölésen” takarítják meg. Az olvasó a Facebookon keresztül tájékozódik, az ott megjelenő könyvtári hírekkel, adatbázistételekkel találkozik. Így érthető, de téves reakció, ha szeretnénk megszokott honlapunk figyelemfelkeltő eszközeként, ízelítővé redukált reklámjaként használni a közösségi médiajelenlét eszközeit. A hivatkozott 4500 bejegyzés recepcióját elemző kutatás kimutatta, hogy a faliújságként, nyitvatartási és gyarapodási híreket közlő, vagy akár területi, gyűjtőköri programajánlóként használt könyvtári Facebook-oldalak sikertelenek, bejegyzéseiket alig veszik észre. A személyes hangvételű, saját gyűjtemény-tételeket komoly hozzáadott értékkel körítő, érdekes háttérinformációkkal megosztó bejegyzések ellenben kifejezetten sikeresek lehetnek.

Sokszor érzékelhető kényszermegoldás az is, hogy a közösségimédia-jelenléttel megbízott munkatárs magánemberként, intézménye mögé bújva, saját érdeklődése, ízlése szerint „posztolgat” számára fontos kulturális vagy tudományos híreket, így pótolva a személyesség átérzett hiányát. Ez a gyakorlat valójában azt eredményezi, hogy a könyvtár jelenléte helyett egy identitását nem vállaló, anonim személy férkőzik ismerőseink közé, az intézményi és gyüjteményi identitástól egyaránt eltávolodva. 
Megkockáztatom: a félreértelmezett közösségimédia-jelenlét hátterében gyakran éppen az áll, hogy a könyvtár mindennapjai elszakadnak a professzionálisan szolgáltatott digitális archívumok lététől. Bár azok tételei megoszthatóak volnának, a könyvtárak nem érzik őket sajátjuknak, s nincs meg a saját felületük, egységesített eljárásuk, bevett gyakorlatuk a közösségi megosztás adekvátabb, professzionális formáira. A Facebook általános közösségi versenypályája így pótcselekvésként, a közösségimédia-jelenlét vegetáló biztosítására ad módot, de sem a megosztások tartalma, sem formája nem tükrözi a korszerű könyvtárképet.

Csak a közösségi médiában legsikeresebb könyvtárak jelenlétét jellemzi a kívánatos kiegyensúlyozottság, a személyes és szakmai hitelesség, az önmagában érdekes és egyedi információk arányossága. Jelentős munkával, de a jelenlegi eszköztárral is mutathatnánk megközelítően teljes, vonzóan interaktív képet magunkról, s fenntarthatnánk azt kincseink rendszeres megosztásával, közvetlen, élettel teli közösségi üzenetekkel, értékes, információban gazdag bejegyzések rendszeres sorozatával. Kevés könyvtár, tudástár, memóriaintézmény képes azonban erre forrást, munkaerőt biztosítani, hiszen a feladat gyakorlatilag a hálózati jelenlét duplikálását jelenti két, egymástól alapvetően eltérő reprezentációs területen, tetézve a könyvtár közösségi életének, műhelyjellegének virtuális leképezésével.

Az ellentmondás így tehát egyrészt abban áll, hogy a könyvtár jövőképében sarkalatos tulajdonságokat - optimális környezet biztosítása, jelenlét közösségként, segítő szakismeret és példamutatás, jó példákkal szolgálás - nem érdemes csonkítani, redukálni a közösségi médiában sem, ám a közösségi média korántsem optimális eszköz azok érzékeltetésére. Hiába is használnánk honlapunkhoz kapcsolt figyelemfelhívó reklámfelületként, ha a közösségi háló üzenetversenye más hozzáállást igényel és jutalmaz, s a versenyképességhez csak limitált (vagy költséges) eszközöket kínál.

Másrészt, a könyvtári szereplehetőség a weben nem pusztán a gyújtemény elemeinek felkínálásában áll, jelentenie kell a kutathatóság, a tudományos összefüggésrendszer kreatív felmutatását, az aktív példamutatást is. Elvárható-e mindez a könyvtári közegtől részben elszakadó virtuális gyűjtemények korában, ha még a könyvtárak mindennapjaihoz legszorosabban köthető honlaptartalmak, eseménydokumentációk és alkalmi rendezvények publikálásában testet öltő hálózati jelenlét is problémát jelent?

A Budapest Gyűjtemény máig is múködtetett megosztás-sorozata, mintapéldaként szolgálhat a könyvtári tudáskincs közzétételére a közösségi médiában. A gyűjtemény vezetője, Sándor Tibor így ír vállalkozásukról: „2014 utolsó száz napján Budapest naprólnapra címmel indítottunk saját oldalt. Minden nap közzétettünk egy összeállítást, amivel egyszerre szerettük volna felkelteni a várostörténet iránti kíváncsiságot és a gyűjteményben fellelhető források változatosságára is ráirányítani a figyelmet. Rövid kommentárok voltak hivatva eligazítani az aznapi kínálatban, de munkatársainkat elragadta a hév: a közléseket egyre igényesebb eseti kutatások előzték meg, a magyarázatok egyre hosszabbak lettek, magunk közül választott lektorunknak pedig kíméletlenül kellett csattogtatnia 


\section{FODOR JÁNOS}

szerkesztői ollóját. A közlemények megírásában mindenki részt vett, beleértve raktárost, közmunkást és szerződéses önkénteseinket is."3

Elvárható-e hasonlóan lelkes csapatmunka minden könyvtártól, s más gyüjtőkörök esetén is, s ki fog hasonló komplex megosztásokat bemutatni a nagy, fizikai könyvtári terekhez nem köthető, digitalizált dokumentum-adatbázisok állományából?

A felhasználók érdeklődését az állományhoz kötő kapcsolat felismeréséhez szakmai kreativitás kell, a megosztás időzítéséhez, kivitelezéséhez szükséges a közösségi média személyes ismerete, a hozzáadott háttéranyag összeállításához pedig a munkatársi összefogás és szakértelem együttállása nélkülözhetetlen. Ha nem is folyamatos szolgáltatásként, de a fenti feltételek a könyvtárakban állnak rendelkezésre. Nem szabad kihasználatlanul hagyni tehát a könyvtárosok szakértelmét, tájékoztatási kedvét és elkötelezettségét gyưjteményük bemutatására. Egy-egy rendezvényhez, részgyűjteményi kiállításhoz vagy új szolgáltatáshoz kapcsolódó hangsúlyos bejegyzésre készülve fontos átgondolnunk, hogy a közösségi médiában minden egyes bejegyzésünk identitásunkat formálja, képviseli. Ideális volna, ha jelenlétünk összességében is hűen, arányosan tükrözné a könyvtár mint intézmény tevékenységeit és funkcióit, de ennél a nagyszabású vállalásnál előrébb való, hogy bejegyzéseink, megosztott tartalmaink önmagukban példázni tudják szakértő, segítő közösségünk jelenlétét a könyvtárban, az ismeretszerzéshez optimális tudástárban.

A közösségi média olyan új felületetet jelent a könyvtár számára, melyen keresztül az író-olvasó felhasználók megoszthatják a gyűjteményeinkre épülő, vagy abból származó ismereteiket, kiteljesíthetik érdeklődésüket és fejleszthetik kompetenciáikat. Ezt az aktivitást elősegíteni, a kutató-tájékozódó érdeklődést gyűjteményünk és szolgáltatásaink felé irányítani csak személyes példamutatással lehet. Egy-egy széles körű érdeklődésre számot tartó, szakértelemmel és elkötelezett hivatástudattal megosztott gyüjteményi tétel többet segíthet ebben, mint az, ha teljes honlap-tartalmunkat fáradtságos munkával, folyamatosan átkonvertáljuk a Facebookra.

A könyvtár kreatív szereplehetőségére a múltban is számos példát találhatunk, én a Poesis Hungarica sorozatot említeném. A hetvenes évek végén, nyolcvanas évek elején elismert és híres bibliofil kötetsorozatot - melynek borítóiból, impresszumaiból Lukoviczki Anna hallgatómmal 2015 tavaszán hoztunk létre emlékhonlapot ${ }^{5}$ - az a Lipták Pál gondozta, aki a békéscsabai könyvtárban dolgozva legendás alakjává vált a magyar könyvtáros szakmának. Lipták Pálnak, a kulturális életet szervező személyiségnek az aktivitása, kreativitása máig érezteti hatását, s képzőművészként, etnográfusként, könyves alkotóként létrehozott életmúvét a halála óta is számon tartja digitalizált emlékezetünk. A Poesis Hungarica Lipták legendás minőség-eszményét szolgáló kreativitása és költő barátja, Fodor András - ma úgy mondanánk - „,kapcsolati hálója” által válhatott a korabeli irodalmi élet szerves részévé, kiegészítőjévé, a hiányzó kötetmegjelenéseket pótló, a lehetőségeket és a centrumtól távolabb születő értékeket felmutató eszközévé. A sorozat 
sikere és rétegkiadványként való elismertsége is bátorította Liptákot további kiadói kezdeményezéseiben (képzőmunvészeti sorozatot indított, a verseskötetek után próza- és esszéköteteket is megjelentetett).

Amiként a kiadás is testreszabott volt - a szerzőkkel egyeztetve, az alkotók régi vágyait, ötleteit vagy hiányzó megjelenéseiket beteljesítő -, úgy felhasználásuk, terjedésük is az irodalmi élet organikus, valós igényeit követte: az aláírt, számozott példányok dedikálva, személyes kapcsolatok mentén kerültek könyvespolcokra, kitüntetett olvasók becsben tartott gyűjteményeibe.

A Poesis Hungarica máig időszerű tanulságát ${ }^{6}$ tehát nem is annyira könyvészeti téren kell keresnünk, mint inkább az egyedi, személyes hitelű információforrások növekvő keresettségében, s a könyvtár szereplehetőségében: az írókat az olvasókkal, az alkotókat a tudásvággyal összekapcsoló aktivitás területén, a mindenkori tartalomszolgáltatásban betölthető rések, rétegigények találékony kielégítésében.

2014 őszén az ELTE Könyvtár- és Információtudományi Intézetének E-könyv, e-olvasás szakmai napján zajló vita ${ }^{7}$ egyik tanulsága éppen az volt, hogy a nyomtatott könyv lehetséges jövőképei között bizonyosan ott szerepel majd az e-kiadással párhuzamos, szorosabb olvasói elköteleződést jelző, gyűjtőszenvedélyt kielégítő vagy épp támogató szponzorációt honoráló papírkönyv, a kis példányszámú, testreszabott bibliofil kiadvány. Ha a hetvenes-nyolcvanas évek szabályozott szerzői jogi viszonyai között múködő, az írásbeliség tekintetében monopol helyzetű könyv- és folyóirat-kiadás közegében létjogosultsága lehetett a Poesis Hungarica 250 példányban megjelenő kiadványainak, akkor létének háttere és körülményei a mai, digitalizált, másolva fogyasztó szövegkultúrában is értékes tanulságokkal szolgálnak.

A nagy, biztonságos, szervezett digitalizálási projektek mellett továbbra is szükség volna a könyvtárak mint egyedi múhelyek aktivitására, a saját gyüjteményüket legjobban ismerő szakemberek megjelenésére alkotó-tájékoztató és tudásmegosztásban példát mutató szakértőként. Intézetünk oktatási programjában kiemelt szerepet kap a tudományos örökség hozzáférhetővé tételéhez szükséges kompetenciák oktatása ${ }^{8}$, de a közeljövő új könyvtári fejlesztései során is fontosnak tartom, hogy erre az aktivitásra is funkciók, alkalmazások dedikáltassanak, s továbbra is nélkülözhetetlennek látom, hogy a szakmai szemléletben hangsúlyos szerepben maradjon a könyvtáros mint kreatív, a webes publikálásban kompetens szakember.

\section{IRODALOM}

${ }^{1}$ Digitális Gyüjtemények = Kutatási Napló. Forrás: http://kutatasinaplo.blogspot.hu/p/digi[-] talibrary.html [2016. január 8.]

${ }^{2}$ FODOR János: A megosztó hivatás: könyvtári jelenlét a Facebook közösségi oldalon 2013/2014ben. = Tudományos és Múszaki Tájékoztatás, 61. évf. 7-8. sz. 2014. 275-294. p.

${ }^{3}$ SÁNDOR Tibor: Helyismeret változó felhasználói környezetben: a százéves Budapest Gyúitemény mai törekvései. $=$ Könyvtári Figyelő, 61. évf. 2. sz. 2015. 157-167. p. 


\section{FODOR JÁNOS}

${ }^{4}$ LUKOVICZKI Anna: A Békés Megyei Könyvtár bibliofil kiadványai. Forrás: http://kuta[-] tasinaplo.blogspot.hu/2015/04/tartalomszolgaltatas-2015-tavasz.html [2016. január 8.]

${ }^{5}$ Poesis Hungarica. Forrás: http://inaplo.hu/poesishungarica [2016. január 8.]

${ }^{6}$ FODOR János: Poesis Hungarica - digitális kontextusban. = Könyv, Könyvtár, Könyvtáros, 24. évf. 6. sz. 2015. 23-26. p.

${ }^{7}$ FODOR János: E-olvasásról a tagadás tükrében: egy bölcsészkari vita tanulságai. = Könyvtári Figyelő, 60. évf. 4. sz. 2014. 481-485. p.

${ }^{8}$ KISZL Péter: Tudományos örökség és gyorsuló fejlődés - könyvtárosképzés az Eötvös Loránd Tudományegyetemen. = Könyvtári Figyelő, 25. (61.) évf. 4. sz. 2015. 443-462. p.

Fodor János az ELTE Könyvtár- és Információtudományi Intézetének adjunktusa. Kutatásai központjában a könyvtárak közösségi média jelenléte áll. A hálózati publikálás és digitalizálás szakértője, egyetemi oktatója. Irodalmárként Fodor András Kossuth-díjas költő posztumusz köteteinek sorozatát rendezte sajtó alá, hátrahagyott életmúvéből a hallgatók bevonásával hálózati életmúkiadást hozott létre. 